\title{
Drivers of Smallholder Plantation Forestry in the Tano North District of Ghana
}

\author{
Godwin Agyemang ${ }^{1} \quad$ Simon Abugre $^{2 *} \quad$ Nat Owusu-Prempeh ${ }^{3}$ \\ 1.Forest Services Division, Forestry Commission, Mankranso, Ghana \\ 2.Department of Forest Science, UENR, Sunyani, Ghana \\ 3. Department of Forest Resources Technology, KNUST, Kumasi, Ghana
}

\begin{abstract}
Adoption of smallholder plantations in off-forest reserve among farmers has always been a challenge. Using the qualitative methods and survey among 193 smallholder plantations farmers through simple random sampling from six communities in the Tano North District, the study aimed at exploring the drivers for smallholder plantation forestry in the Tano North District of the Brong-Ahafo Forest Region of Ghana. The findings showed that as age of farmers increased, the number of plantations owned reduced. Surprisingly, all the plantations owned by farmers were teak. In addition, a significant relationship between gender of farmers and factors that motivated them to establish smallholder plantations was identified. Furthermore, the relationship between gender and land tenure systems was significant. The study identified low price for teak wood, absence of standard price for teak wood, decline in food crop yield due to canopy closure of teak stands, lack of capital to invest in teak plantation, lack of extension services from Forest Services Division and wildfire as the factors that militate against smallholder plantation forestry. The motivating factors for smallholder plantation forestry were financial returns, plantation as collateral to secure loans, hobby and construction material for subsistence use. The identified drivers if taken into account during the implementation of smallholder forestry could enhance its viability and adoption.
\end{abstract}

Keywords: gender, land tenure, land size, age, militating factors, relationship

DOI: $10.7176 / \mathrm{JNSR} / 10-6-04$

Publication date:March $31^{\text {st }} 2020$

\section{INTRODUCTION}

Forests on the earth's surface continue to be important not only for their unique hardwoods and non-wood forest products but also for protecting the most precious parts of the Earth's biodiversity (Lawrence, 1999). Kuntz and Siegert (1999) reported that forests are of great importance for local climatic processes since they play a crucial role in climate regulation and constitute one of the major carbon sinks. However, these benefits are under threat because of deforestation and forest degradation (Lambin, 1994).

Forest areas throughout the world continue to decline at a rate of about 7.3 million hectares (18 million acres) per year, an area equivalent to Panama and Sierra Leone as a result of deforestation (FAO, 2005). FAO (2001) mentioned that from 1990-2000, the loss in forest area in Africa was 5.3 million hectares annually, corresponding to an annual rate of $0.8 \%$. From 2000-2010, the forest area loss was 3.4 million hectares annually, corresponding to an annual deforestation rate of $0.5 \%$. In Ghana, the annual deforestation rate is $2.1 \%$ per year which corresponds to an average annual forest loss of 115,000 ha (FAO, 2010).

In order to address deforestation, forest degradation and related problems, forest plantations are being carried out across the globe (Parrotta, 1992). In Ghana, different forest plantation models such as smallholder plantation (SHP), 'expanded plantation programme', modified taungya system, government plantation development programme, and private commercial forest plantation development have been used to establish forest plantations (Agyeman, 2004; FC, 2008; Foli et al., 2009; Hoogenbosch, 2010). Most of these plantation schemes are established in forest reserves. Few, such as smallholder plantations (SHP) and private commercial plantations are established off-reserve. SHPs are generally defined as trees planted on lands up to 10 ha or less and mostly rely exclusively on family labour (Salam et al., 2000). The Timber Resource Management (Amendment) Act 2002 (Act 617) and the Forest Plantation Development Fund, Act 583 in 2000 are aimed at encouraging farmers to establish SHP in their farmlands (Insaidoo et al., 2012). The promotion of SHP is likely to compete with agriculture for land. Knowledge of the drivers that enhance SHP could be used by extensionist to promote the adoption of SHP. Currently some farmers have been involved in SHP in the district. However, no information exists on categories of farmers adopting SHP. The study also sought to identify motivating and militating factors that affect SHP. This would expand timber resource base and improve livelihood of farmers practising smallholder plantation forestry.

\section{MATERIALS AND METHODS}

Description of the Study Area

The establishment of plantation has taken place in the Forest Zone of Ghana since the early 1970s (Nsiah, 2010). However, only few districts have been able to implement SHP activities successfully. The Tano North District is one of the Districts with a long tradition of successful implementation of plantation activities, hence the decision 
to carry out the study in this district. The District lies between Latitudes $7^{0} 00^{\prime} \mathrm{N}$ and $7^{0} 25^{\prime} \mathrm{N}$ and Longitudes $2^{0}$ $03^{\prime} \mathrm{W}$ and $2^{0} 15^{\prime} \mathrm{W}$. It has a total land area of $837.4 \mathrm{~km}^{2}$ and constitutes about $1.8 \%$ of the total land area of the Brong Ahafo Region (Ghana Statistical Service, 2014).

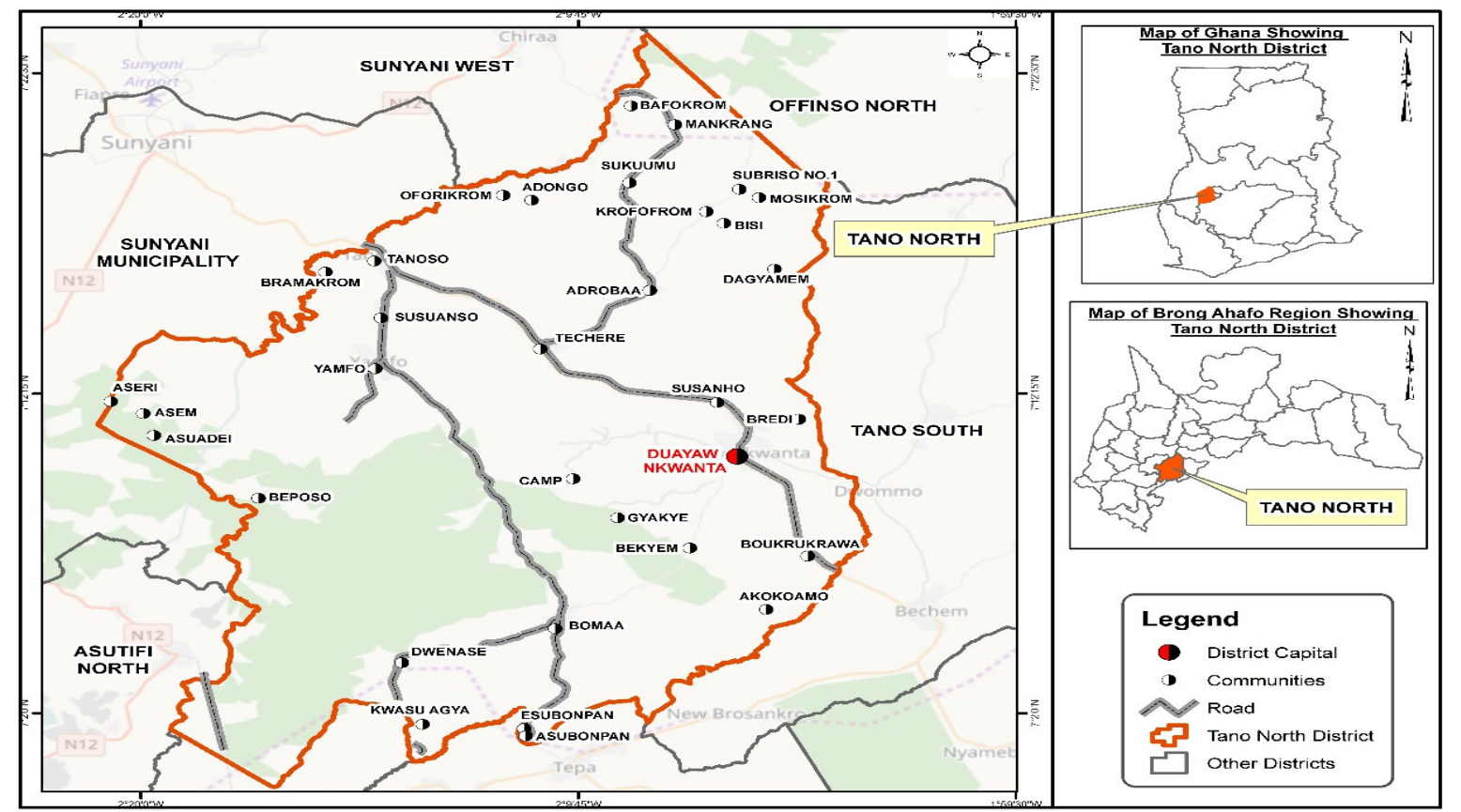

Figure 1: Map of the Study Area

\section{Data collection methods}

A list of communities with smallholder plantations (SHP) within the Tano North District were sought with the assistance of the Regional Forestry Office, Sunyani. From the list, six (6) communities out of nineteen (19) communities with SHP within the district were selected using simple random sampling technique. The sampling was done to ensure that each of the communities would have equal chance of being selected. The sample size of communities was determined by using the mathematical formula: $n=N / 1+N(e)^{2}$ (Gomez and Jones, 2010), where $n$ is the sample size, $N$ is the sample frame (i.e. the total number of communities with smallholder plantations within the District) and $e$ is the margin of error. Applying the mathematical formula, in each of the communities, the total sample size for the study was 193 SHP farmers.

\section{Data Collection Tools and Techniques}

The main tools for data collection included questionnaires and Global Positioning System (GPS) devices whilst data collection techniques involved interviews and individual discussions. The selected SHP farmers were interviewed individually using semi-structured questionnaire. The questionnaire captured data on sociodemographic characteristics, number of farms owned, motivation factors for SHP; and the factors that militate against SHP. Also, key informants were interviewed and discussions with them offered the opportunity to obtain further information for validation. This process helped in ensuring that the data obtained were accurate reflection of the study. Field visits were made to SHP owned by the farmers that were sampled. The overarching purpose of the visits was to verify SHP data obtained from the interviews. Global Positioning System (GPS) devices were used to pick the geographic coordinates of smallholder plantations belonging to the sampled farmers for Geographic Information System (GIS) analysis.

\section{Analysis of data}

The data captured by the questionnaires were processed (i.e. edited and coded) and analysed using the Statistical Package for Social Science (SPSS) 18.0. Tools used in the analysis were mainly descriptive statistics, analysis of variance (ANOVA), correlation and chi-square analysis. While the descriptive statistics were used to describe the socio-demographic characteristics (mainly in the form of frequencies and percentages), the chi-square analysis and correlation were carried out to determine relationships among some of the variables. The GPS coordinates of smallholder plantations were processed and analyzed using ArcGIS software 10.4 to determine the size of the land for smallholder plantation forestry. 


\section{RESULTS}

Relationship between age of farmers and number of plantations owned by SHP farmers

Table 1 shows the relationship between age of farmers and number of plantations owned. A weak negative relationship ( $\mathrm{r}=-0.116)$ was obtained between age of farmers and number of plantations owned. This indicates that as the age of a farmer increases, the number of plantations owned reduces. With an aging population in farming, this could be detrimental to SHP.

Table 1: Relationship between age of farmers and number of plantations owned

\begin{tabular}{|c|c|c|c|}
\hline Variables & Statistics & Age & Number of plantations owned \\
\hline \multirow[t]{2}{*}{ Age } & Pearson Correlation (r) & 1 & -.116 \\
\hline & $\mathrm{N}$ & 193 & 193 \\
\hline \multirow{2}{*}{$\begin{array}{l}\text { Number of plantations } \\
\text { owned }\end{array}$} & Pearson Correlation (r) & -.116 & 1 \\
\hline & $\mathrm{N}$ & 193 & 193 \\
\hline
\end{tabular}

\section{Relationship between gender and size of plantation owned}

The group statistics in Table 2 showed that the average size of plantations owned by male plantation farmers was 3.842 ha with a standard deviation of 1.8096 ha while that of their female counterparts was 3.769 ha with a standard deviation of 1.2590 ha. An indication that males have larger SHP than females. The average size of plantations owned by male plantation farmers was not significantly different from the average size of plantations owned by female plantation farmers $(\mathrm{t}=0.265$, $\mathrm{p}$-value $=0.791)$ at the 0.05 level of significance. Even though, many males are into SHP, the size of plantations does not differ among the sexes.

Table 2: Relationship between gender and size of plantation owned

\begin{tabular}{llllll}
\hline \hline & Gender & $\mathrm{N}$ & Mean & Std. Deviation & Std. Error Mean \\
\hline Size of plantation & Male & 142 & 3.842 & 1.8096 & .1519 \\
& Female & 51 & 3.769 & 1.2590 & .1763 \\
\hline \hline
\end{tabular}

Relationship between gender and number of plantations owned

The average number of plantations owned by male plantation farmers was 1.16 with a standard deviation of 0.456 while that of their female counterparts was 1.18 with a standard deviation of 0.385 (Table 3 ). In terms of the number of plantations owned, it did not differ among the sexes $(\mathrm{t}=0.203$, p-value 0.840$)$, although SHP is predominantly male dominated.

Table 3: Relationship between gender and number of plantations owned

\begin{tabular}{llllll}
\hline \hline & Gender & $\mathrm{N}$ & Mean & Std. Deviation & Std. Error Mean \\
\hline Number of plantations owned & Male & 142 & 1.16 & .456 & .038 \\
& Female & 51 & 1.18 & .385 & .054 \\
\hline \hline
\end{tabular}

\section{Size of Land for Smallholder Plantation Forestry}

From the 193 smallholder plantation farmers who were selected for the study, they worked on 225 plantation plots with a total size of 737.7 ha. On average, each farmer possessed 3.8 ha of smallholder plantation (Table 4). The smallest plot from the data collected was 0.8 ha, whilst the largest was 9.2 ha (Table 4).

Table 4: Size (ha) of smallholder plantation plot owned by farmers

\begin{tabular}{lllll}
\hline Community & Number of farmers & Number of plots & Total plot size (Ha) & Average plot size (Ha) \\
\hline Techire & 56 & 69 & 259.3 & 4.63 \\
Adrobaa & 49 & 53 & 151.4 & 3.09 \\
Yamfo & 39 & 42 & 132.1 & 3.39 \\
Bomaa & 20 & 24 & 85.6 & 4.28 \\
Tanoso & 17 & 21 & 67.8 & 3.99 \\
Duayaw- & & & \\
Nkwanta & 12 & 16 & 41.5 & 3.46 \\
Total & $\mathbf{1 9 3}$ & $\mathbf{2 2 5}$ & $\mathbf{7 3 7 . 7}$ & Overall average $=\mathbf{3 . 8 2}$ \\
\hline
\end{tabular}

Source: Field Survey, 2017

Further analyses showed that majority of the farmers (30.57\%) owned plantation plots ranging from 1-2.9 ha whilst $23.32 \%$ possessed plots that fell between 3-3.9 ha. Furthermore, $19.69 \%$ and $11.40 \%$ of the farmers owned 4-4.9 ha and 5-5.9 ha plantation respectively (Figure 2). 


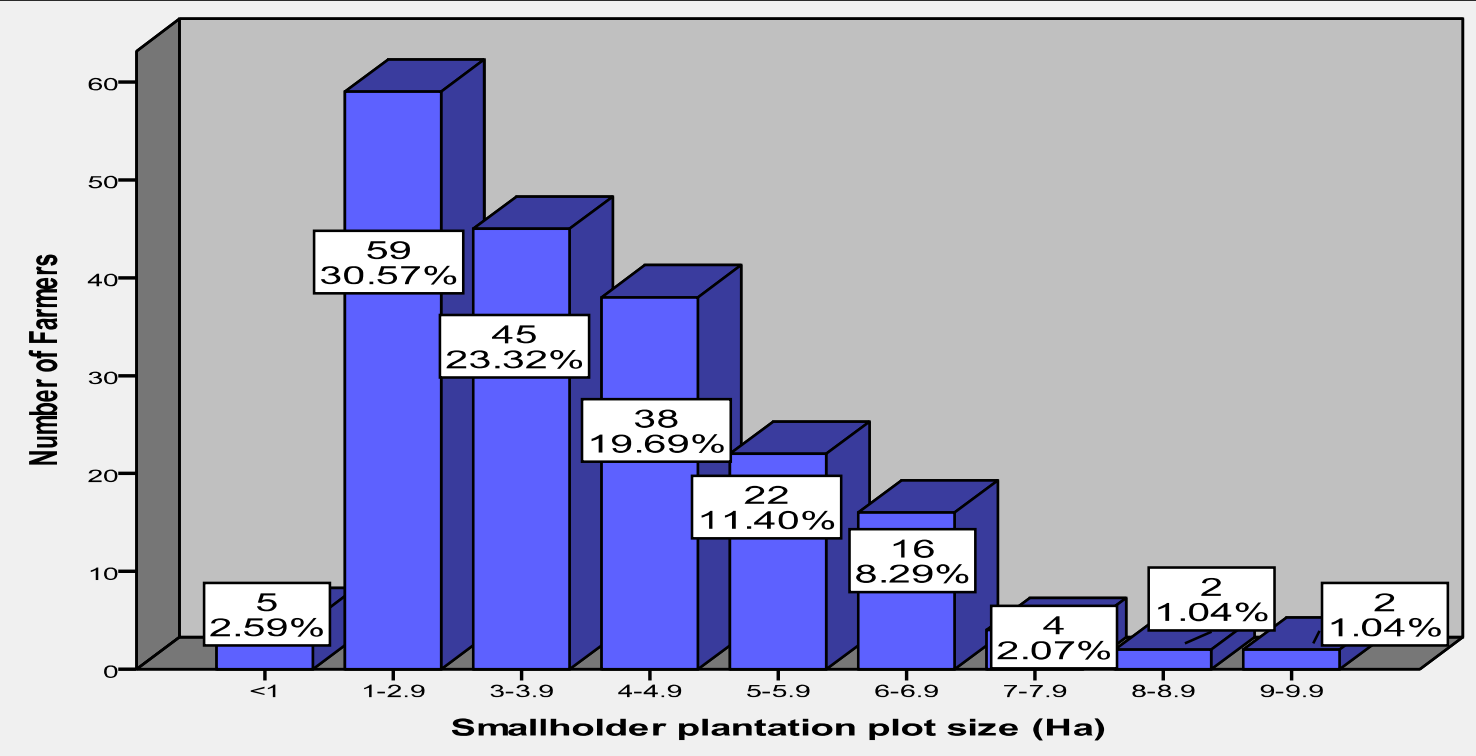

Figure 2: Size (ha) distribution of smallholder plantation plot owned by famers Source: Field Survey, 2017

\section{Land Tenure System and Smallholder plantation}

Smallholder plantation farmers operated under three main land tenure systems. Majority $(71.0 \%)$ were under 'indigenous land-use rights' in which land was acquired for farming by virtue of one being a member of a family. Furthermore (21.2\%) hold 'outright ownership' over lands they cultivate. These farmers acquired the land either by purchase or gift. Other farmers (7.8\%) who were mostly migrants got land for establishing smallholder plantation through share-cropping popularly referred to as "Abunu or Abusa".

\section{Relationship between gender and factors that motivated farmers to establish plantations}

The results showed that $86.6 \%$ of male plantation farmers were motivated by financial returns whilst $2.8 \%$ established their plantations as a hobby. Among the 51 female plantation farmers, $52.9 \%$ were motivated by financial returns while $4.1 \%$ were motivated by ability to use wood as construction material (Table 5).

Table 5: Relationship between gender and factors that motivated farmers to establish plantations

\section{Factors that motivate respondents to establish plantation}

\begin{tabular}{|c|c|c|c|c|c|c|}
\hline \multirow[b]{2}{*}{ Gender } & & \multicolumn{4}{|c|}{ Factors that motivate respondents to establish plantation } & \multirow[b]{2}{*}{ Total } \\
\hline & & Financial returns & Hobby & $\begin{array}{l}\text { Plantation as a } \\
\text { collateral to secure } \\
\text { loans }\end{array}$ & $\begin{array}{l}\text { Construction } \\
\text { material for } \\
\text { subsistence use }\end{array}$ & \\
\hline & \multirow[t]{2}{*}{ Male } & 123 & 4 & 10 & 5 & 142 \\
\hline & & $86.6 \%$ & $2.8 \%$ & $7.0 \%$ & $3.5 \%$ & $100.0 \%$ \\
\hline & \multirow[t]{2}{*}{ Female } & 27 & 6 & 15 & 3 & 51 \\
\hline & & $52.9 \%$ & $11.8 \%$ & $29.4 \%$ & $5.9 \%$ & $100.0 \%$ \\
\hline \multirow[t]{2}{*}{ Total } & & 150 & 10 & 25 & 8 & 193 \\
\hline & & $77.7 \%$ & $5.2 \%$ & $13.0 \%$ & $4.1 \%$ & $100.0 \%$ \\
\hline
\end{tabular}

Analysis indicates significant relationship between gender of farmers and factors that motivated them to establish plantations (Chi-square $=26.274$, -value $=0.000)$ at the 0.05 level of significance.

\section{Relationship between land tenure systems and size of plantation}

The study identified the average size of plantations owned by farmers who use family lands for their plantation to be 3.653 ha with a standard deviation of 1.6732 ha while those who practice share-cropping were 3.867 ha with a standard deviation of 1.6260 ha. The average size of plantations owned by farmers who have outright ownership of their lands was 4.373 ha with a standard deviation of 1.6354 ha (Table 6). The ANOVA indicate land tenure systems and size of plantation were not significantly different $(\mathrm{P}$-value $=0.054)$. 
Table 6: Land tenure and size of SHP

\begin{tabular}{|c|c|c|c|c|c|c|c|c|}
\hline \multirow[b]{2}{*}{ Groups } & \multirow[b]{2}{*}{$\mathrm{N}$} & \multirow[b]{2}{*}{ Mean } & \multirow{2}{*}{$\begin{array}{l}\text { Std. } \\
\text { Deviation }\end{array}$} & \multirow{2}{*}{$\begin{array}{l}\text { Std. } \\
\text { Error }\end{array}$} & \multicolumn{2}{|c|}{$\begin{array}{l}\text { 95\% Confidence Interval for } \\
\text { Mean }\end{array}$} & \multirow[b]{2}{*}{ Minimum } & \multirow[b]{2}{*}{ Maximum } \\
\hline & & & & & Lower Bound & Upper Bound & & \\
\hline Family & 137 & 3.653 & 1.6732 & .1430 & 3.370 & 3.935 & .8 & 9.2 \\
\hline Share-cropped & 15 & 3.867 & 1.6260 & .4198 & 2.966 & 4.767 & 1.6 & 6.4 \\
\hline $\begin{array}{l}\text { Outright } \\
\text { ownership }\end{array}$ & 41 & 4.373 & 1.6354 & .2554 & 3.857 & 4.889 & 1.6 & 7.6 \\
\hline Total & 193 & 3.822 & 1.6789 & .1208 & 3.584 & 4.061 & .8 & 9.2 \\
\hline
\end{tabular}

\section{Relationship between gender and land tenure systems}

The study found that majority $(64.1 \%)$ of the male plantation farmers use family lands for their plantations and only $10.6 \%$ practice share-cropping. Also, an overwhelming majority $(90.2 \%)$ of female plantation farmers use family lands for their plantations while $9.8 \%$ own the lands they use for their plantations (Table 7). Analysis of data indicate a significant relationship between gender and land tenure systems (Chi-square $=13.262, \mathrm{p}$-value $=$ 0.001 ) at the $5 \%$.

Table 7: Cross tabulation between gender and land tenure systems

\begin{tabular}{llllll}
\hline \multirow{2}{*}{ Gender } & & \multicolumn{2}{l}{ Land tenure systems } & \\
\cline { 3 - 6 } & Mamily & Share-cropped & Outright ownership & Total \\
\hline & 91 & 15 & 36 & 142 \\
& $64.1 \%$ & $10.6 \%$ & $25.4 \%$ & $100.0 \%$ \\
\cline { 3 - 6 } & Female & 46 & 0 & 5 & 51 \\
& $90.2 \%$ & $.0 \%$ & $9.8 \%$ & $100.0 \%$ \\
\hline Total & 137 & 15 & 41 & 193 \\
& $71.0 \%$ & $7.8 \%$ & $21.2 \%$ & $100.0 \%$ \\
\hline \hline
\end{tabular}

\section{Factors militating against smallholder plantation}

The factors that were identified to militate against SHP were low price for teak wood $(60.6 \%)$, absence of standard price for teak woods $(17.1 \%)$, decline in food crop yield due to canopy closure of teak stands $(7.8 \%)$, lack of capital to invest in teak plantation (6.2\%), lack of extension services from Forest Services Division $(5.2 \%)$ and Wildfire (3.1\%) (Figure 3).

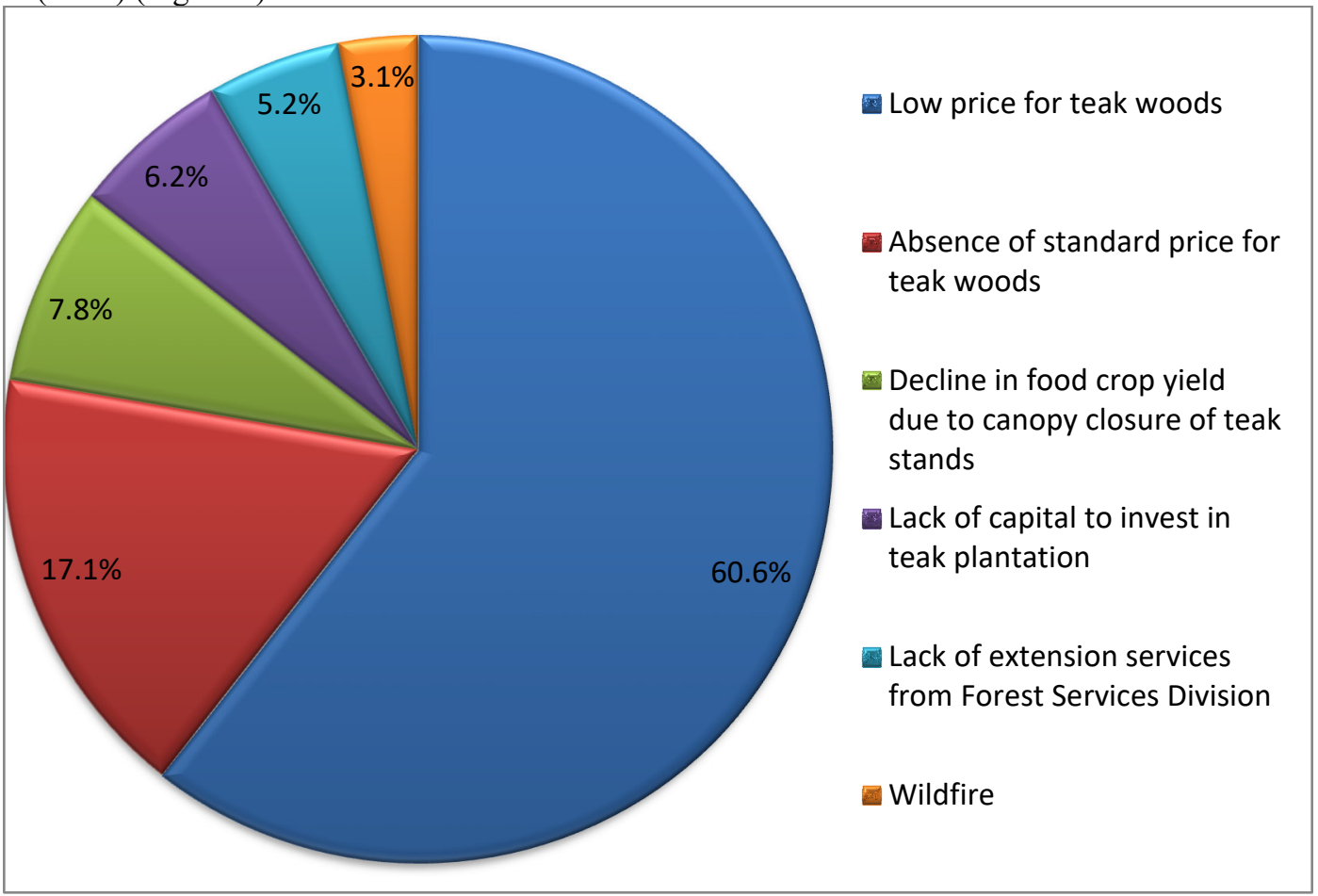

Figure 3: Factors militating against teak plantation Source: Field Survey, 2017 


\section{DISCUSSION}

\section{Socioeconomic characteristics of smallholder plantation farmers}

The practice of smallholder plantation forestry exclusively by men perhaps portrays gender issues. The women probably see plantation forestry as occupation for men. Though few women were into smallholder plantation forestry, the average size of their plots was not significantly different from the average size of plantations owned by their male counterparts. This could be attributed to the matrilineal inheritance system in the study area. Apart from the fact that the system allows females to have access to family lands, it also allows females to have larger size of family lands than males (Aidoo, 1996). Gender analysis is also significant to the adoption model with men found to be more likely to adopt

bamboo agroforestry than women (Akoto et al., 2018). This is consistent with the findings of this study, however, the large farm size by females is due to the inheritance system practised in the study area.

The low number of aged farmers practising smallholder plantation forestry could be due to the fact that they do not have the necessary energy to work and manage smallholder plantation as compared to the active working group. A negative age-plantation size relationship observed in a study (Osei, et al., 2018). They stated that tree planting is mostly ideal for younger and middle-aged farmers (Meijer et al., 2015). Furthermore, they explained that Older farmers may also be less motivated to undertake largescale reforestation projects because they may probably be dead before the trees mature for harvest (Boni 2006; Meijer et al. 2015). The study has showed that as the age of a farmer increased, the number of plantations owned reduced. This could be attributed to physical strength required for smallholder plantation forestry. The decline in physical strength after middle age might make old farmers having multiple plantation plots, abandon some of these plantations. Especially, in cases where the distances between the plantations are far. In addition, looking at the relative long rotation period of plantation establishment, at old age, their interest to continue SHP might not be high, so they might not focus on having multiple plantation plots but rather pursue more short-term benefits.

The major source of labour for working and managing smallholder plantation in the study area was family labour. Therefore, the high number of farmers who were married and practising smallholder plantation forestry could be due to the help received from household labour. Household labour represents an important factor in the production activities of households (Current et al., 1995). The non-availability of labour is often cited as a constraint to adoption of smallholder plantation forestry. Hence, lack of household labour force will prevent farm households from engaging in long-term economic activities such as forest plantation development (Current et al., 1995).

\section{Land Tenure System and SHP}

According to Kassanga, (1998) the term "land tenure" applies to the various laws, rules and obligations governing the holding and/or ownership of rights and interests in land. The variety of land tenure arrangements is consistent with observation made by Odoom, (1999) that farmers in Ghana operate under various land tenure systems. The indigenes in the study area were mostly practising smallholder plantation forestry. This could be due to the fact that they have permanent land (usually through family inheritance and outright purchase). Customarily, planting of trees on any parcel of land implies ownership, thus debarring settler/migrant farmers from undertaking such a venture (Djagbeletey et al., 2007). It is therefore clear that farmers with permanent land are more likely to adopt SHP.

\section{Gender of Farmers and Factors that Motivated them to Establish Plantations}

The study has shown that there is a significant relationship between gender of farmers and factors that motivated them to establish plantations. This suggests that certain motivation factors are peculiar to females and males. For instance, majority of male plantation farmers established plantations in anticipation of financial returns whilst females were motivated by its use as construction material. This implies that preferences for SHP among gender differs. Men are always looking at the financial benefits obtained whilst females look at the households needs to be derived from SHP. Most studies have identified economic returns as a motivating factor in plantation forestry (Osei et al., 2018, Acheampong et al., 2016) but have failed to segregate the motivation based on gender.

\section{Gender and Land Tenure Systems}

Results from the study showed that the relationship between gender and land tenure systems is significant. This suggests that certain land tenures are peculiar to females and males. It was found that only males adopted sharecropping system for the establishment of smallholder plantations whiles overwhelming majority of their female counterparts also used family lands. Family lands in the study area which are mostly used by females could be attributed to the matrilineal inheritance system practised in the area. This system enables females to have greater access to family lands than males. 


\section{Motivation Factors for Smallholder Plantation Forestry}

The main motivation factor for smallholder plantation forestry in the Tano North District was anticipation of financial returns. This finding supports Salam et al., (2000) who reported that most of the farmers in tropical countries practise smallholder plantation forestry for financial returns. To promote smallholder plantation forestry, there is the need to make it attractive for farmers to get the necessary financial benefit. According to Osei et al., (2018), the provision of incentives was key to encourage reforestation. Further, lack of income from the Modified Taungya System between tree canopy closure (when the cultivation of food crops is no longer possible) and timber harvesting demotivates farmers and discourages them from tree farm maintenance (Acheampong et al., 2016). The economic value of woody perennials is a key factor in farmers' adoption of a technology (Scherr 1995). Dejene et al. (2018) report that the concept of conservation and forest development is supported by the majority of the respondents and about $40 \%$ are dependent on the forests for income generation. Introducing trees with low gestation period could further enhance the financial benefits.

\section{Factors Militating Against Smallholder Plantation}

The variety of factors militating against smallholder plantation is consistent with the observation made by Insaidoo, et al., (2012) that there are several constraints to the development of forest plantations in the tropics. Most of the farmers in the study area have therefore decided to convert their teak plantation into either cocoa, cashew or food crop farm. The farmers' unwillingness to continue with teak plantation was attributed to low prices for teak woods, absence of standard price for teak woods, decline in food crop yield due to canopy closure of teak stands, and lack of capital to invest in teak plantation. The farmers' intentions to convert their teak plantation into either of the above-mentioned crop farms showed that the farmers see crop farming as more profitable than teak plantation. In order to sustain smallholder plantation forestry in the study area, the Forestry Commission together with the Ministry of Lands and Natural Resources should design and implement policies that would seek to address the factors militating against smallholder plantation in the study area.

\section{CONCLUSION}

Generally, the study showed that demographic characteristics such as age and gender could influence the adoption SHP. Furthermore, age had a negative relationship with number of plantations owned. The motivation factors for smallholder plantation forestry were financial returns, plantation as collateral to secure loans, hobby and construction material for subsistence use. There is a significant relationship between gender of farmers and factors that motivated them to establish smallholder plantations. Also, the relationship between gender and land tenure systems was significant. The study found that there was an insignificant relationship between land tenure systems and size of plantation. The factors that militate against smallholder plantation were low price for teak woods, absence of standard price for teak woods, decline in food crop yield due to canopy closure of teak stands, lack of capital to invest in teak plantation, lack of extension services from Forest Services Division and wildfire. It is therefore important that the identified drivers be explored to promote SHP.

\section{ACKNOWLEDGEMENT}

We are very grateful to the Regional Forestry Office, Sunyani, for providing us the list of SHP farmers. Without whom we could not have carried out the study.

\section{REFERENCES}

Acheampong, E., Insaidoo, T. F. G. and Ros-Tonen, M. A. F. (2016). Management of Ghana's modified taungya system: challenges and strategies for improvement. Agroforestry System 90:659-674.

Agyeman, V.K. (2004). Plantation Development in Ghana: policy, silviculture, institutional arrangement and funding mechanism in Cobbinah, J.R, Ofori, D.A and Bosu, P.P. (eds.). Pest Management in Tropical Plantations. International Workshop Proceedings, 21-23 July, 2004, pp. 17-31

Aidoo, J. B. (1996). Our common estate tenancy and the land reform debate in Ghana. The Royal Institute of Chartered Surveyors. London

Akoto, D. S., Denich, M., Partey, S. T., Frith, O., Kwaku, M., Mensah, A. A., and Borgemeister, C. (2018). Socioeconomic Indicators of Bamboo Use for Agroforestry Development in the Dry Semi-Deciduous Forest Zone of Ghana. Sustainability10: 1-13.

Boni S. 2006. Ghanaian farmers' lukewarm reforestation: environmental degradation, the timber option and ambiguous legislation. Paper presented at the Colloque international "Les frontiers Southern Forests 2018: 1-8 7 de la question foncière: Enchâssement social des droits et politiques publiques", 17-19 May 2006, Montpellier, France.

Current, D., Lutz, E. and Scherr, S. J. (1995). The costs and benefits of agroforestry to farmers. The World Bank Research Observer (10): 151-80.

Dejene, T., Kidane, B. Yilma, Z. and Teshome, B. (2018). Farmers' perception towards farm level rubber tree 
planting: a case study from Guraferda, South-Western Ethiopia.

Forestry Research Engineering International Journal 2:192-196.

Djagbeletey D.G., Adu-Bredu S. (2007). Adoption of agroforestry by small-scale teak farmers-the case of Nkoranza District. Ghana Journal of Forestry, Vol. 20\&21

FAO, (2001). Deforestation continues at a High Rate in Tropical Areas, State of World's Forests, The Food and Agriculture Organisation, (FAO), Rome

FAO, (2005). Global biodiversity assessment, 2002, FAO, Rome, 127pp.

FAO (Food and Agriculture Organization of the United Nations). (2010). Forest Resources Assessment. Rome: FAO.

FC (Forestry Commission of Ghana). (2008). National Forest Plantation Development Programme (NFPDP): Annual Report 2008

Foli, E., Agyeman, V.K., Pentsil, M. (2009). Ensuring Sustainable Timber Supply in Ghana: a case for plantations of indigenous timber species. Forestry Research Institute of Ghana, Technical Note No. 1, pp. 15

Ghana Statistical Service (2014). 2010 Population and Housing Census: District Analytical Report. Tano North District. GSS, Ghana.

Gomez, B. and Jones, P.J. (2010). Research methods in Geography. John Wiley \& Sons Ltd. The role of microfinancing in sustainable forest management

Hoogenbosch, L. (2010). Forest plantations and livelihoods in Ghana's high forest zone. MSc thesis University of Amsterdam.

Insaidoo, F.G.T, Mirjam A.F. Ros-Tonen, Emmanuel Acheampong, E. (2012). On-Farm Tree Planting in Ghana's High Forest Zone: The Need to Consider Carbon Payments

Kasanga, K.R. (1998). Land tenure and development dialogue: the myth concerning communal land holding in Ghana. Occasional Paper No. 19. Cambridge, UK, Department of Land Economy, University of Cambridge.

Kuntz, S., \& Siegert, F. (1999). Monitoring of deforestation and land use in Indonesia with multitemporal ERS data. International Journal of Remote Sensing, 20 (4), 2835-2853

Lambin, E. F. (1994). Modelling Deforestation Processes-A Review: Tropical Ecosystem Environment Observation by Satellites (TREES)-Research Report No. 1. Institute for Remote Sensing Application. Joint Research Centre, Commission of the European Communities.

Lawrence, W.F. (1999). Reflections on the tropical deforestation crisis. Biological Conservation 91: 109-119.

Meijer, S. S., Catacutan, D., Sileshi G. W., Nieuwenhuis, M. (2015). Tree planting by smallholder farmers in Malawi: using the theory of planned behaviour to examine the relationship between attitudes and behaviour. Journal of Environmental Psychology 43: 1-12.

Osei, R., Zerbe, S., Beckmann, V. and Boaitey, A. (2018). Socio economic determinants of smallholder plantation sizes in Ghana and options to encourage reforestation. Southern Forest 1: 1- 8.

Parrotta, J. (1992). The role of plantation forests in rehabilitating degraded tropical ecosystems. Agricultural Ecosystem and Environment 41:115-133.

Salam, M.A., Noguchi, T. and Koike, M. (2000). Understanding why farmers plant trees in the homestead agroforestry in Bangladesh. Agroforestry Systems 50(1): 77-93.

Scherr, S.J. (1995) Economic factors in farmer adoption of agroforestry: Patterns observed in Western Kenya. World Dev. 23: 787-804. 